\title{
THE APRIL MEETING OF THE AMERICAN MATHEMATICAL SOCIETY.
}

A Regular meeting of the American Mathematical SocIETy was held in New York on Saturday, April 30th. Thirty persons were in attendance, including the following twenty-three members of the Society : Dr. J. B. Chittenden, Professor F. N. Cole, Dr. J. W. Davis, Mr. G. B. Germann, Professor James Harkness, Professor Harold Jacoby, Mr. C. J. Keyser, Professor Pomeroy Ladue, Professor E. O. Lovett, Mr. James Maclay, Professor W. F. Osgood, Mr. J. C. Pfister, Professor A. W. Phillips, Professor James Pierpont, Professor C. A. Scott, Professor W. E. Story, Mr. W. M. Strong, Professor H. D. Thompson, Professor J. M. Van Vleck, Professor E. B. Van Vleck, Professor A. G. Webster, Miss E. C. Williams, and Professor R. S. Woodward.

The meeting extended through a morning and an afternoon session. The First Vice-President of the Society, Professor R. S. Woodward, occupied the chair. The Council announced the election of the following persons to membership in the Society : Mr. Carl C. Engberg, University of Nebraska, Lincoln, Neb. ; Professor Gaetano Lanza, Massachusetts Institute of Technology, Boston, Mass. ; Mr. Derrick N. Lehmer, South Omaha, Neb. ; Dr. G. A. Miller, Cornell University, Ithaca, N. Y.; Professor Eugene R. Smith, Cazenovia Seminary, Cazenovia, N. Y. ; Mr. Alva C. Washburne, New York, N. Y. ; Mr. William H. Williams, State Normal School, Platteville, Wis. Four applications for membership were received.

The By-Laws of the Society were amended to provide for life-membership, the dues being fixed at fifty dollars, exclusive of initiation fee.

The following papers were presented :-

(1) Professor W. F. Osgood :- "Example of a singlevalued function with a natural boundary, whose inverse is also single-valued."

(2) Mr. J. K. WhitTemore :-" A proof of the theorem :

$$
\frac{\partial^{2} f(x, y)}{\partial x \partial y}=\frac{\partial^{2} f(x, y)}{\partial y \partial x}
$$

(3) Mr. H. E. HAwKEs : - "The limitations of Greek arithmetic." 
(4) Professor H. S. White :- "The construction of special regular reticulations on a closed surface."

(5) Professor E. O. LovetT :- "Infinitesimal transformations of concentric conics.'

(6) Professor E. O. Lovet :- "Note on infinitesimal projective transformations."

(7) Professor Maxime Bôcher :- "Note on Poisson's integral."'

(8) Mr. W. M. Strong:- "On the necessity of continuity in Euclid's geometry.'

(9) Professor A. G. Webster :-_" Note on Stokes's theorem in curvilinear coördinates."

(10) Professor E. B. VAN VLeCK :- "On the polynomials of Stieltjes."

(11) Mr. G. P. Starkweather :-" A solution of the biquadratic by binomial resolvents."

(12) Dr. G. A. Miller :- "On the supposed five-fold transitive function of 24 elements and $19 ! \div 48$ values."

(13) Dr. G. A. Miller :- "On the Hamilton groups."

The papers of Professor White and Dr. Miller, and Professor Lovett's first paper were read by title. The papers of Professor Bôcher and Mr. Whittemore were presented by Professor Osgood, and Mr. Starkweather's paper by Professor Pierpont.

Most of the papers presented have been or will be published in the Bulletis.

Dr. Miller's first paper will be offered for publication in the Messenger of Mathematics. In his "Mémoire sur l'étude des fonctions de plusieurs quantités," which was published in Liouville's Journal, 1861, p. 241, Mathieu proves the existence of the remarkable five-fold transitive function of 12 elements and 7 ! values. In the same memoir he states (p. 274) that he has found a five-fold transitive function of 24 elements which has $19 ! \div 48$ values, and in a memoir bearing the title, "Sur la fonction cinq fois transitive de 24 quantités," whioh was published in the same Journal in 1873 , he gives some details in regard to this function.

If such a function existed there would be a five-fold transitive substitution group of degree 24 and order $48 \cdot 20 \cdot 21 \cdot 22$. 23.24 . By means of Sylow's theorem Dr. Miller proves that such a substitution group cannot be constructed. Hence the given five-fold transitive function of 24 elements does not exist.

Columbia University.

F. N. Cole. 